\title{
Fighting 'on the side of little girls': feminist children's book publishing in France after 1968
}

Article

Accepted Version

Heywood, S. (2020) Fighting 'on the side of little girls': feminist children's book publishing in France after 1968. Nottingham French Studies, 59 (2). pp. 206-220. ISSN 0029-4586 doi: https://doi.org/10.3366/nfs.2020.0285 Available at https://centaur.reading.ac.uk/87239/

It is advisable to refer to the publisher's version if you intend to cite from the work. See Guidance on citing.

Published version at: https://www.euppublishing.com/doi/abs/10.3366/nfs.2020.0285

To link to this article DOI: http://dx.doi.org/10.3366/nfs.2020.0285

Publisher: Edinburgh University Press

All outputs in CentAUR are protected by Intellectual Property Rights law, including copyright law. Copyright and IPR is retained by the creators or other copyright holders. Terms and conditions for use of this material are defined in the End User Agreement.

www.reading.ac.uk/centaur

\section{CentAUR}


Central Archive at the University of Reading

Reading's research outputs online 


\section{FIGHTING 'ON THE SIDE OF LITTLE GIRLS':}

\section{FEMINIST CHILDREN'S BOOK PUBLISHING IN 1970S FRANCE}

\section{Sophie HEYwOOD}

'One is not born, but rather becomes, a woman'. ${ }^{1}$ This famous line from Simone de Beauvoir's Le Deuxième Sexe [The Second Sex] (1949) bears repeating in a special issue on childhood in France, since with this brief phrase the philosopher established the importance of child-rearing to the post-suffrage feminist struggle. Beauvoir's distinction between a person's biological sex, and the social and cultural norms that forge their gender identity led her to unpick how young girls were moulded to conform to such norms from birth through to adulthood, using insights drawn from psychoanalysis, literature and philosophy. This basic methodological framework was adapted with gusto by feminist thinkers and militants in the 1970s. Several of the factions within the Mouvement de Libération des Femmes [MLF, Women's Liberation Movement] turned their attentions to childhood. Through the medium of print, feminists produced new narratives of girlhood in several successful series of books for children, inspired by studies on sexism in child-rearing. While the French second-wave feminist movement and its publishing activities have been well-documented, relatively little attention has been paid to its attempts to imagine childhood free from sexism. ${ }^{2}$

Feminists of the period were not alone in rethinking children's culture in the light of their militant aims. Kimberly Reynolds speaks of the 'transformative energy of children's literature', noting that the importance of childhood to developing citizens of the future means writing for children has regularly 'been put into the service of those who are trying to disseminate new world views, values and models' ${ }^{3}$ Certainly around the epochal year of 1968 , the search for new forms of social organization and political action led to a re- 
examination of power structures, including the family, and inspired a search to find new ways of speaking to children. ${ }^{4}$ Children's book publishing in France around 1968 was an important site for radical experimentation. ${ }^{5}$ For some politically engaged publishers, alternative forms of culture for children were perceived to offer a 'second front', to borrow the term employed by the French author and editor Christian Bruel, through which to effect change where the revolution of 1968 had failed. ${ }^{6}$ While a good proportion of the anti-sexist children's books were produced by feminist presses who did not specialize in children's books - principally the Du Côté des Petites Filles [On the Side of Little Girls] series for MLF's Éditions des Femmes - other radical publishers also became interested in feminist children's books, notably Christian Bruel's publishing collective Sourire qui Mord [The Smile that Bites]. In fact, these different presses often published many of the same experimental artists and authors. Feminist publishing for children was aesthetically, as well as politically innovative. The relationships between these distinct publishers can shed light on how feminist campaigns helped shape the new ideas on children and their culture that emerged around 1968.

This article traces how ideas on psychoanalysis and sex difference as being socially constructed, and the many tensions within these two large and interconnected intellectual currents produced new ways of thinking about books for children in the 1970s. In children's literature studies, scholarship on feminism in children's books has tended to focus on the texts, and how feminist theory revolutionized the way that children's books have been written, read and interpreted. ${ }^{7}$ This article shifts the focus instead to the producers, to trace the key role played by certain feminist organizations with their affiliated presses, and by radical publishing collectives in pioneering an anti-sexist approach to making children's books. Through an examination of their publishing practices, collaborators and books, the article explores not only the intellectual impact of the women's liberation movement on 
children's literature, but also the artistic visions and new poetics they helped to inspire and nurture.

\section{The feminist challenge to child-rearing practices}

Revisiting childhood was integral to many feminist analyses of gendered oppression. This is not to suggest there was a cohesive 'feminist' perspective on childhood in the 1970s. Rather, the discussions reflected the myriad divisions that characterized the second wave feminist movement in France: it was more important for some schools of thought than for others. ${ }^{8}$ Notably, the group Psychanalyse et Politique [Psychoanalysis and Politics, usually referred to as Psych et Po], and particularly its charismatic co-founder, Antoinette Fouque, stressed the importance of the early years, when the child resolves the Oedipus complex and enters into the symbolic order of the phallus. Psych et Po sought to recover the feminine element that had been suppressed, through a variety of techniques, including psychoanalysis and developing 'feminine' writing (écriture féminine), freed from the shackles of patriarchal conventions. The second major current of thought to be interested in childhood was that of the radical feminists, guided by the Beauvoirian theory that the education of little girls forces them into the rigid structures of womanhood. Studies in the 1970s of sex roles and the socialization of children included a special issue of Les Temps Modernes on books for girls in 1976 (Beauvoir was on the magazine's editorial board). ${ }^{9}$ The most influential publication however was a book entitled $\mathrm{Du}$ Côté des Petites Filles by the Italian Montessori practitioner, Elena Gianini Belotti. ${ }^{10}$ She analysed how even before birth, parents' and society's expectations conditioned the lives of boys and girls according to their gender. When Belotti's book was translated into French (paradoxically, given their opposing views) by Psych et Po's publishing house, Éditions des Femmes in 1974, it proved to be one of their best-selling books, and still is to this day, having sold over 300,000 copies since its release. ${ }^{11}$ Moreover, 
as Anne Meunier remarks, it became the go-to feminist book for parents after '68, and remains a key reference for discussion of gender stereotypes (the thick folder of recent press clippings in the Éditions des Femmes archives is testimony to this). ${ }^{12}$

Child-rearing was thus one way to ensure the cycle of patriarchal repression was broken, and children's books were key to this approach. In French feminism, the social constructivists led the campaigns against sex-role socialization, concerned about the negative impact on young girls of outmoded representations in children's books on family life, gender roles and career expectations. Feminist campaign groups in the 1970s, such as Beauvoir's Ligue du Droit des Femmes [Women's Rights League], attacked school textbooks for their representation of traditional sex roles. This argument was given national prominence as it became the subject of one of the first campaigns led by the newly-appointed Under-Secretary of State for Women's Condition, Françoise Giroud, when she commissioned an inquiry in 1974 into sexism in primary schools. ${ }^{13}$ Besides schools, children's literature was identified as one of the main ways in which patriarchal norms were transmitted across the generations. As Simone de Beauvoir put it, 'little girls explore the world and see their destinies through the eyes of men. ${ }^{14}$ Belotti devoted almost thirty pages of her book to detailing the findings of studies on children's books, myths and legends, and the ways in which they perpetuated girls' subaltern status. ${ }^{15}$ She highlighted the systematic relegation of female characters to the background of plots, the reduction of women to the role of mother, and the confinement of heroines to passive roles. Only wicked witches or stepmothers played an active role in stories. Challenging such misogyny was all the more urgent, according to Belotti, because she subscribed to a functionalist understanding of children's reading, in which young readers had no critical faculty, and therefore internalized completely what they read in their books. ${ }^{16}$

Divisions emerged over what the remedy to this situation might be. They broadly fell into tensions between social constructivists' emphasis on societal factors, which applied to 
both sexes, and Psych et Po's own theories of sex difference predicated on a feminist reading of psychoanalysis. In fact, the Éditions des Femmes editors added their response to Belotti's thesis on the back cover of their edition of her book: 'should we conclude, as the author does, that we should simply be developing the child's 'human' qualities, regardless of their sex? Might not such an egalitarian and undifferentiated education risk a further integration into the schemas of masculine oppression? ${ }^{\prime 17}$ This was typical of the Éditions des Femmes use of what Sweatman calls 'framing strategies', in which the editors would signal their disagreement when the author's conclusions did not fit with Psych et Po's analysis of women's condition. ${ }^{18}$ Psych et Po argued vociferously that the ultimate challenge to the masculine order would come only from women (mothers, lovers, writers) nurturing a revitalized, powerful form of the feminine. ${ }^{19}$ The main question was therefore whether feminist books for children should play down the differences between girls and boys, as the constructivists suggested, or instead seek to promote a new, female-led society? What would this look like? Moreover, when it came to portraying girls' bodies, and girls as desiring subjects, these divisions became more complex. Such questions struck at the heart of the second-wave movement, and its claims to bodily autonomy and reproductive rights. Sex education and fostering in girls a positive relationship with their bodies from their early years were key tenets of this revolution.

For both Beauvoir and Belotti, the major elements of gender difference were socially constructed, rather than lying in the psyche. Both suggested that Freud's famous thesis on female penis envy was describing a phenomenon that had social, rather than psychological origins. Feelings of inferiority could be eradicated in a more egalitarian society. For Psych et Po, by contrast, sex difference was inscribed in the body and the psyche. Their emphasis on the feminine, and the emancipatory possibilities of female homosexuality caused problems when it came to representing heterosexual desire in children's books. Nevertheless, such 
tensions could be productive in terms of books for children. As the Éditions des Femmes commentary on Belotti's book concluded: 'the immense success of this book clearly shows that this is one of the sensitive areas of debate [points névralgiques] of the women's struggle.'

\section{'Opening the conversation' with children about sexism}

The success of Belotti's book inspired several publishers to answer her call for a new type of children's literature, as well as to tap into the substantial market of mothers who wanted to educate their children with books that reflected the values of the feminist revolution. The pioneer in this regard was Adela Turin, an Italian feminist militant. ${ }^{20}$ Turin had spent the early 1970s in Paris, where she had become involved with the MLF, before moving to Milan where she joined the radical feminist movement 'Rivvolta femminile'. Interested in the publishing house Éditions des Femmes from its inception in 1972, Turin had at that point discussed with its director, Antoinette Fouque, the idea of producing feminist children's books. Thus in 1975, when she started a children's publishing project named Dalla Parte delle Bambine after Belotti's book, she contacted Éditions des Femmes. The French house was delighted to support Turin's new venture - Bibia Pavard speaks of their 'coup de foudre' for her books ${ }^{21}$ - and the two outfits set up a co-edition agreement to produce the new series in both Italian and French.

The primary function of books in this series was to be employed as tools in the feminist struggle against the patriarchy, or rather, as Turin put it, as 'a means, not an end'. ${ }^{22}$ These were 'militant books', whose aim was to open 'the conversation with children, and provide adults with arguments in order to talk to children about sexism'. ${ }^{23}$ In this respect, the Franco-Italian series was probably the first large-scale venture of its kind in Europe. ${ }^{24}$ Comparable children's books were being produced by other women's liberation movements 
in the United States: the Group 22 collective in North Carolina, for example, set up the Lollipop Power publishing group, which used children's picturebooks as part of their consciousness-raising work, and as a way to extend the discussion about child-rearing. ${ }^{25}$ Lollipop Power's publishing practices were deliberately counter-cultural, non-hierarchical, and with very little editorial work before the books were put into production. ${ }^{26}$ Éditions des Femmes in France adopted similar non-hierarchical approaches to business (aided by a large initial donation and subsequent funding from Sylvina Boissonais), and placed an emphasis on the collective in its publishing practices, often producing books unsigned by authors. ${ }^{27}$

By way of contrast to both its American counterparts, and its French publisher, the Italo-French series Du Côté des Petites Filles was the product of two women's editorial vision: Adela Turin, who edited the series as well as writing most of the books, and Antoinette Fouque, who commissioned a number of French titles. The partnership produced nine books in the first year of its existence, between 1975 and 1976, five of them written by Adela Turin and illustrated by Nella Bosnia. ${ }^{28}$ The books had a cohesion, and an editorial line on female childhood that was distinctive, but still allowed some disagreement. In addition, theirs was a professional, international and avowedly entrepreneurial venture. ${ }^{29}$ The partnership allowed Turin to use advance payments on the rights from the French edition to defray the production costs involved in making large, full-colour picturebooks. She boasted to the historian Bibia Pavard that they were the most dynamic section within the Éditions des Femmes press, whose books helped to raise the press's public profile, and that it was the only series to have print runs of 50,60 even 80,000 copies ${ }^{30}$ Certainly they proved adept at international distribution, and further partnerships were set up in 1976 with the Spanish publisher Lumen, and the English Writers and Readers Publishing Cooperative. ${ }^{31}$ The series recruited some of the brightest young female talents of the children's publishing scene in France, notably Agnès Rosenstiehl and Nicole Claveloux. These women were professionals 
rather than feminist militants. The latter in particular was at that point an internationallyrecognized artist (she won the Biennial of Illustration Bratislava's Golden Apple Prize in 1976), and her collaboration indicated that the aim of Du Côté des Petites Filles was to produce books both politically and aesthetically innovative. The balance between producing commercially viable, artistically daring and militantly feminist books was not, however, an easy balance to strike, and ultimately the priority always had to be the ideological struggle.

The series opened in a riot of pink, with a picturebook for young children entitled Rose Bombonne [original Italian title Rosaconfetto, English translation Sugarpink Rose]. ${ }^{32}$ On the surface everything about the book spoke loudly of reclaiming the feminine: its pink spotty cover, featuring a pink elephant in a frilly pram, the series logo with a young girl next to the feminist clenched fist, and the book's ultra-girly title. The story itself then subverts this association of the female and the pink. It tells how a little elephant frees herself from the tyranny of the sickly pink world in which she is forced to live. The tribe of elephants forces its daughters to eat peonies and anemones, and play in a confine, in order to develop a beautiful soft pink skin. One little elephant, Pâquerette [Daisy], finds her skin stays stubbornly grey, despite all her efforts to eat the flowers. In a rage, her father accuses her of being a rebel, and warns she will never find a husband. Pâquerette decides she has had enough, and escapes the girls' pen to join the boys, frolicking freely in the mud and the forest. The other girls follow suit, and the book concludes that henceforth it will be impossible to tell boy elephants from girl elephants. This was the first openly militant feminist children's book in 1970s France - Pâquerette was presented as a 'petite éléphante en lutte' [a militant little girl-elephant] in the accompanying publicity. ${ }^{33}$ Published in a series that had taken its name from Belotti's big bestseller, Rose Bombonne came into the shops just as the government was leading a national debate on the topic. The book therefore attracted 
much media attention, and, as we shall see below, inspired other publishers to join the struggle.

Rose Bombonne's rather Beauvoirian happy ending, in which gender difference was all but eradicated, does not appear to have troubled Fouque and her team. Nevertheless, Adela Turin's writing swiftly moved towards an emphasis on the powerful qualities of womanhood, which was more in tune with the ethos of her French partners. Increasingly her books ended with female characters setting up all-female communities. Men, or male characters (be they tortoises, bonobos or elephants) tended to be associated with violence, injustice, and capitalism, from which the female characters had to emancipate themselves in order to found more just and harmonious societies. Turin made this division explicit in an interview with her illustrator, included at the end of her later book for teenagers, Ariane: entre les lignes d'une légende [Arianna, tra le righe di una leggenda], (1979/80), a feminist adaptation of the myth of Theseus and the Minotaur. She stated that she saw in the story 'two types of relations: the tender alliance between three women... and the brutal connivance between Theseus and Pirithous focused on violence and power. ${ }^{34}$ The critics who celebrated Turin's works pointed to her caustic critiques of contemporary male-dominated capitalist society. In 1976, Edwige Talibon-Lapomme, writing for Le Monde, evaluated the whole production of the series thus far (six books). ${ }^{35}$ She considered that in the third, fourth and subsequent books in the series, Turin's writing had developed in a far more interesting direction, once she had evidently decided to abandon male society as a model that girls should aspire to join. Talibon-Lapomme commended Turin's Clémentine s'en va [Arturo e Clementinal Arthur and Clementine], for its depiction of the hollow life of a man (well, a tortoise) who is addicted to consuming things to the point where he only wants to be a spectator, rather than truly live life. When his wife Clementine expresses an interest in music, he buys her a record player, when she wants to try painting, he buys her a picture, until she 
begins to feel crushed by this paraphernalia. Eventually, Clementine escapes her heavy shell to go travelling around the world on her own. Turin's evolving vision of the ideal society can be seen in the Histoire des Sandwiches [Storia di Paninil The Breadtime Story], illustrated by Margherita Saccaro (1976), which, as Pavard notes, could be read as a metaphor for the MLF itself. ${ }^{36}$ In this picturebook a little girl's curiosity helps the women in her village understand that their labour, making delicious sandwiches, is being exploited by the men in the city. The women go on strike, and eventually, set up a women-led community. Saccaro's images played with perspective, to underscore the theme of growth - the women grow in stature as they regain control over their lives. The final double-page spread imagined this feminine community, where all inhabitants are deliberately represented as being the same size, (even the children), and all are engaged in group activities. A few men feature in the final utopian vision of the Sandwiches. However, many of Turin's books concluded that women were quite simply, better off without men. L'Histoire Vraie des Bonobos à Lunettes [La Vera Storia dei Bonobo con gli Occhiali/ The Real Story of the Bonobos who Wore Spectacles], (1976) for example, ends with the female bonobos gathering up the children and setting up their own 'calm and peaceful' existence in the mangroves, away from their exploitative male overlords.

The desire to criticize patriarchal society also led Turin to rewrite fairy tales, considered by feminist scholars to be leading offenders in encouraging girls to simply wait passively for their prince to come. As Lissa Paul writes, fairy tales enjoyed a 'new lease of life' as a result of the 1970s fashion for subverting such tales, one of the distinctive features of the feminist poetics of children's culture across the West in this period. ${ }^{37}$ According to Paul, the hallmark of these second-wave fairy tales was that they simply changed the originals, so that the heroines were like their male counterparts. ${ }^{38}$ However, the strategies adopted by Adela Turin suggest that Paul's criticism, while surely valid, downplays the militant, educational function of such tales. Turin's books provided girls with feminist 
versions of classic tales, but she also used framing devices to highlight the literary strategies that male-dominated society had long used to keep girls and women in their place. She wanted her books to open conversations between adults and children. Thus her feminist edition of Hans Christian Andersen's Poucette [Thumbelina] (1978) opened with an explanation of why the happy marriage at the end of the tale had been removed: 'we don't want to tell little girls tall stories any more [nous ne voulons plus raconter des histoires aux petites filles] ${ }^{\prime} \cdot{ }^{39}$ Her edition of La Petite Sirène [The Little Mermaid] (1980) told readers that they had decided at the very last minute to give Andersen's story a happier conclusion, 'the poet, on being consulted, shrugged his shoulders: women's struggles are not his concern. ${ }^{40}$ Fairy tales raised the thorny question of romantic (heterosexual) love. Turin was uncompromising on this question. Nicole Claveloux, the artist whom Turin had commissioned to reimagine Andersen's fairy tales, ${ }^{41}$ recalled how the editor had required all references to love, 'whether it be the hope of finding love, or waiting for a prince to come', to be removed. Turin's view was that girls should be encouraged to see there was happiness in a career, or in friendships, or in travelling, instead of reading 'sexist fairy tales fabricating this dream of love'. This was a stance that Claveloux found difficult to accept. ${ }^{42}$ For the artist, Turin's suggested 'happy' ending for the Sirène, in which the heroine's sisters encourage her to murder her rival bride, so that the little mermaid might return to her ageing parents, was 'nightmarish!'. According to Christian Bruel, the penultimate image in the feminist Sirène, in which the mermaid is depicted curled up in the shape of a question mark, was the artist's way of discreetly protesting against this conclusion. ${ }^{43}$ (Unfortunately, because Turin was not credited with her editorial role, most of the critics who were appalled at this treatment of the text blamed Claveloux for the changes). ${ }^{44}$ Above all, Claveloux felt that the idea in these feminist versions of both of Andersen's tales, in which returning home alone, without love forms the happy ending, 'is such an austere, even puritanical, ending to propose to poor little 
girls. ${ }^{45}$ All the same, the books, dominated by Claveloux's outlandish, disturbing images, make a bold statement on feminist poetics, far removed from straightforward subversion. The small detailed images in Poucette are set out across the pages, echoing the diminutive heroine. The front cover of her Sirène amplifies Claveloux's feelings of the nightmarish elements of the story. A young girl's face, framed by dripping, slimy seaweed emerges wideeyed out of the water, against a dark red and black background. These were not beautiful heroines waiting for romantic love. Turin's choice of Claveloux, one of the artists of the children's avant-garde, was an aesthetic one, that of a feminist publisher, promoting experimental female art. Unsurprisingly though, given their disagreements, Sirène was the last Éditions des Femmes project that Claveloux worked on.

\section{The female body and search for identity}

Integral to finding new ways to speak to children, and particularly girls, was the importance of celebrating their bodies, in order to overturn the narratives of secrecy and shame that were particularly dominant in Catholic countries such as France and Italy. The findings of psychoanalysis on human sexuality and how it develops from birth, as well as the ideas of May '68, had given campaigns for sex education greater impetus. ${ }^{46}$ Children's publishing responded with a proliferation of books on the subject. As Jean Delas of the new publisher L'Ecole des Loisirs recalled: 'this was the great era of sex education, for all ages, even for the under threes! 47

It was Antoinette Fouque who secured for the Éditions des Femmes the artist who would produce one of the most audacious books from this period for younger readers on female sexuality. Fouque had been impressed by the work of artist and writer Agnès Rosenstiehl, notably Rosenstiehl's early effort De la Coiffure [Hairstyles], from 1968, 
depicting a little girl's imagining of the baroque styles she would wear if she had long hair, ${ }^{48}$ which Fouque re-edited in the Du Côté des Petites Filles series. Then she commissioned Rosenstiehl to write a book about girls for the series. The resulting work, Des Filles [Girls], published in 1976, brought not only girls to centre stage, but also the female libido. ${ }^{49}$ The idea for the book came from Rosenstiehl's desire to break the silence around girls' bodies. She recalled how she was affected by her mother's laconic reaction when she told her she had begun menstruating: 'Ah! It's happened' ${ }^{50}$ The young Agnès was given no further information by her mother, and had to find out for herself what was happening to her body. Rosenstiehl came from an artistic family, but one which still adhered to the conventions of the time surrounding female sexuality and girls' upbringing: 'we were brought up to be completely ignorant of our bodies and our sexuality'. ${ }^{51}$ Rosenstiehl brought a playfulness to the series, contrasting with the more militant tone of Turin's books. Her beguilingly simple drawings in Les Filles skewered patriarchal assumptions about female sexuality and tackled taboo subjects such as sex, menstruation, and desire.

The book's cover featured a series of identically dressed girls and one lone boy. In the foreground, a girl with a grin on her face and a speech bubble saying 'héhé' reaches out for the boy's crotch. Rosenstiehl placed the publisher's name, Éditions des Femmes, on the boy's sweatshirt, so he was effectively labelled as belonging to women. Inside, a boy and girl compare their genitalia, and, in a cheeky feminist riposte to Freud's theory of female castration anxiety, they hold a peeing competition, where the girl pees standing up: both accuse the other of cheating. ${ }^{52}$ She takes delight in telling him that later she will have periods, with 'blood!' written in a large speech bubble, and responds angrily to the boy's suggestion that she can't be an architect, that she will be like her mother and stay at home. She details all the fantastic things girls can do. Their argument is resolved: the girl studies her companion and two thought bubbles betray her attraction to this 'cute'... 'phallocrat'. But although 
'Antoinette was delighted with the result', the ambiguity surrounding the implications of her decision for the girl's destiny (would she marry the boy and become like her mother?) was not the feminist ending envisioned by Fouque. ${ }^{53}$ The female libido was one of the key ways in which feminist thinkers in the Psych et Po current sought to challenge the phallocratic order. Thus the final image of the book, still in Rosenstiehl's hand, expresses the editors' disappointment, as a group of agitated-looking girls state in a collective speech bubble: 'It's hard for us to see such a promising beginning of emancipation conclude with a traditional conjugal ending! We hope there will be a more militant and subversive sequel. Long live the struggle!' As Claveloux had, Rosenstiehl found the atmosphere in the press too serious for her liking; 'they were militants' ${ }^{54}$ (Julia Kristeva would accuse the publishing house of being 'a sect more dogmatic than the Communist Party' ${ }^{55}$ ). However, both Claveloux and Rosenstiehl underscored in later interviews the sense of complete freedom they enjoyed in the books they produced. Such framing strategies ensured that disagreements usually remained an open and frank exchange, in which they invited their young readers to reflect on the big feminist debates of the day.

Finally, Turin and Fouque's feminist publishing project inspired one of the most enduringly successful examples of a meditation on sex difference and the embodied experience of gender in contemporary French children's literature. The Du Côté des Petites Filles series, and particularly Rose Bombonne had caught the attention of a collective calling itself 'Pour un autre merveilleux' ['For different fairy tales'], founded by Christian Bruel. This was a group of researchers, teachers, journalists, psychologists and artists dedicated to analysing contemporary children's books. The collective's first pamphlet placed their work in the context of the 'new wind' that was 'blowing in the land of publishing for young children', in which 'hitherto taboo themes are beginning to be discussed' ${ }^{56}$ Given their brief, the collective studied Rose Bombonne carefully, and according to Bruel, it inspired them to 
launch their own publishing project. ${ }^{57}$ The result was Histoire de Julie qui avait une ombre de garçon [Story of Julie with a boy's shadow], a sombre picturebook focusing on the emotional impact of growing up in a home where parents make their love conditional on their children conforming to their ideals. In the case of Julie, this was because she fails to behave like other girls. One day, she discovers her shadow is that of a boy. According to Anne Bozellec, another collective member who illustrated the book, the idea came from discussions with a young girl, who showed them a drawing she had done in which she had buried herself to escape her shadow. They decided this idea could be a good way to start exploring the search for identity. ${ }^{58}$ Julie is a tomboy, or garçon manqué in the Freudian sense of the term, that of a very physical lack which embodies her inferiority: 'maybe she was just a boy... a failed boy [garçon manqué], with just this slit between her thighs that she liked to gently touch'. The use of the shadow device further underscored the way in which Julie's difference is inscribed in her body. The book closes with Julie meeting a boy, as she is attempting to bury her shadow, and they both realize that they have the right to be who they are. Both will, however, have to return home to an unchanged situation. Against all their expectations, the book did well. Within nine months Julie had sold five thousand copies, and was warmly received by critics. Adela Turin also responded to their homage, by translating Julie into Italian in 1978, while her Spanish partner published their edition in $1980 .{ }^{59}$ For Bruel, Julie came at just the right time: it 'seemed to answer a need for hope'. ${ }^{60}$

\section{Conclusion}

This brief overview of some of the major publications carried out by publishers affiliated with the women's liberation movement, and the experimental publications and collectives they also inspired, has highlighted several tensions within this production, which, I have argued, proved as stimulating as they were divisive. The main fault line, the point 
névralgique identified by the Éditions des Femmes, one central to the feminist movement within France as a whole, was the difference between a social constructivist vision of gender as opposed to an embodied, even essentialist understanding of sex difference. However, for all sides of the debate, early childhood was the origin of the problem, and therefore the site of the solution. The second paradox was also the one which made the French feminist publishing scene from this period particularly distinctive, and that was the tension between the desire of professional publishers such as Turin and Fouque to draw upon the female talents of the vibrant children's book scene in France and Europe, to produce aesthetically challenging books, and their aim as feminist militants to produce tools for the struggle. French feminist children's picturebook publishing in the 1970s was inspired by this need to produce alternative tools for child-rearing, but it also sparked new directions within the children's field to produce an alternative literature, in which 'different fairy tales' were possible.

Finally, these may have been relatively marginal publishers, but their books enjoyed significant success. As Turin remarked, simply publishing for a feminist audience led to producing books for a mass movement, made up of millions of women across Europe ${ }^{61}$ She also noted that books by feminist theorists such as Hélène Cixous were aimed at intellectuals and members of the MLF. Turin's children's books had a much wider readership: 'I don't think there would have been such popular interest in Éditions des Femmes if they had only published Cixous...' ${ }^{62}$ The considerable sales of these books also provide further evidence that the question of child-rearing was by no means marginal to the feminist movement. This was not only one of the major debates of the movement, a point névralgique, but also an issue that demanded action, to provide the tools for the struggle. Moreover, a substantial number of the titles remain in print: Turin and Bosnia's Rose Bombonne has been adapted and re-edited as Rose Bonbon by Actes Sud (1999, 2008), Rosenstiehl's Les Filles returned in 2018, in a 
new edition by La Ville Brûle, and Bruel and Bozellec's Histoire de Julie has been more or less continuously in print since its publication in 1976, with a new edition produced by Éditions Thierry Magnier in 2014. They form important precursors to the new school of nonsexist children's books that caused ferocious debates in 2014, when the conservative politician Jean-François Copé castigated schools for promoting what he called 'gender theory'. Histoire de Julie was cited by Le Figaro as a 'classic' in this subversive genre. ${ }^{63}$

The author would like to thank Éditions des Femmes for kindly opening their archives; Nelly Chabrol Gagne for her guidance on the Christian Bruel archives; and Christian Bruel and Nicole Claveloux for agreeing to be interviewed.

${ }^{1}$ Simone de Beauvoir, Le Deuxième Sexe [The Second Sex] 2 vols, (Paris: Gallimard, 1949). On childhood, see vol. 2, Chapter 'Formation'.

${ }^{2}$ Studies on the MLF include: Claire Duchen, Feminism in France: from May '68 to Mitterrand (London: Routledge, 1986); Lisa Greenwald, Daughters of 1968: redefining French feminism and the women's liberation movement (Lincoln, London: University of Nebraska Press, 2018). On the publishing activities of the MLF, see Bibia Pavard, Les Éditions des femmes: Histoire des premières années, 1972-1979 (Paris: L'Harmattan, 2005); Jennifer L. Sweatman, The Risky Business of French Feminism: Publishing, Politics, and Artistry (Lanham: Lexington Books, 2014). Both Sweatman and Pavard have brief sections on the children's series, but this is not the main focus of their studies.

\footnotetext{
${ }^{3}$ Kimberly Reynolds, Radical Children's Literature: Future Visions and Aesthetic Transformations in Juvenile Fiction (Houndmills: Palgrave Macmillan, 2007), p. 2.

${ }^{4}$ See Julie Pagis, May '68 : shaping political generations, transl. by Vicki Whittaker, (Amsterdam: University of Amsterdam Press, 2018), chapter 5; also Sophie Heywood, 'Children's 68: introduction', special issue of Strence [Online], edited by Sophie Heywood and Cécile Boulaire, 'Le '68 des enfants / The Children's '68', 13 (2018); 〈https://journals.openedition.org/strenae/1769> [Accessed 31 May 2019].
} 
${ }^{5}$ On this period, see Images à la Page. Une histoire de l'image dans les livres pour enfants (Paris, Gallimard Jeunesse, 1984) ed. by Christiane Clerc et al.; '1965-1975, la mutation d'un paysage ?', special issue of Revue des livres pour enfants, 244 (2008); the special issue of Strence [Online], edited by Sophie Heywood and Cécile Boulaire, 'Le '68 des enfants / The Children's '68'; on the post '68 publishing landscape in France see Jean-Marie Bouvaist and Jean-Guy Boin, Du printemps des éditeurs à l'âge de raison: les nouveaux éditeurs en France (1974 - 1988) (Paris: La Documentation française/ SOFEDIS, 1989).

6 'Sous les pavés, l'album: des influences croisées d'une période et d'un genre littéraire', Revue des livres pour enfants 244 (2008), 89-97, esp. pp. 95-6.

${ }^{7}$ On feminism and children's literature, the scholarship is vast. Lissa Paul's essay 'Feminism Revisited', in Understanding Children's Literature: Key Essays from the Second Edition of the International Companion Encyclopedia of Children's Literature, ed. by Peter Hunt (London: Routledge, 2005) pp. 114-27, provides an excellent overview and bibliography. Nelly Chabrol Gagne's Filles d'albums. Les représentations du féminin dans l'album (Le Puy-en-Velay: L'atelier du poisson soluble, 2011) offers a historically-informed overview of how girls and women are represented in French-language picturebooks. Recent work on feminism and gender in children's literature in France is compiled in Etre une fille, un garçon dans la littérature pour la jeunesse: France 1945-2012 ed. by Christiane Connan-Pintado and Gilles Béhotéguy (Bordeaux: Presses Universitaires de Bordeaux, 2014). Little research on second-wave feminism has been done, aside from Leslie Paris's essay 'Happily Ever After: Free to Be ... You and Me, Second-Wave Feminism, and 1970s American Children's Culture', in The Oxford Handbook of Children's Literature, ed. by Lynne Vallone and Julia Mickenberg, 520-35. On the contemporary feminist publishing scene in France, see Julie Fette 'Gender in Contemporary French Children's Literature: The Role of Talents Hauts', Children's Literature Association Quarterly, 43 (2018) 285-306, but this offers only a brief discussion of earlier efforts.

${ }^{8}$ The movement tends to be roughly divided into three main factions: class struggle (socialist feminism), radical feminists, and Pysch et Po, although some have pointed out that this schema is reductionist. See Greenwald, Daughters of 1968, chapter 4, especially p. 131.

${ }^{9}$ For an extensive bibliography of such studies, see Fette, 'Gender'.

${ }^{10}$ Elena Gianini Belotti, Du côté des petites filles, French translation by collective (Paris: Éditions des Femmes, 1974), transl. by Lisa Appignesi et al. as Little Girls: Social Conditioning and its Effects on 
the Stereotyped Rôle of Women During Infancy (London: Writers and Readers Publishing, 1975). The edition used here is the paperback French version, from Éditions des Femmes' 'pour chacune' series, 10e edition, 1974.

${ }^{11}$ Sweatman, Risky Business, p. 49.

${ }^{12}$ Anne Meunier, 'Trente ans après, du côté des petites filles', La lettre de l'enfance et de l'adolescence (51) (2003) 99-104 (p. 101).

${ }^{13}$ For more information, see Sweatman, Risky Business, pp. 75-78 and Rebecca Rogers and Françoise Thébaud, La Fabrique des filles: l'éducation des filles de Jules Ferry à la pilule (Paris: Les Éditions Textuel, 2014) 144-56.

${ }^{14}$ Beauvoir, Deuxième Sexe, 2, pp. 36-7.

${ }^{15}$ Belotti, Petites filles, pp. 135-159. The following analysis is based on this section of the book.

${ }^{16} \mathrm{Ibid}$. pp. 158-9. For a critique of perspectives on children's reading, see Karin Lesnik-Oberstein, Children's Literature: Criticism and the Fictional Child (Oxford: Clarendon Press of the Oxford University Press, 1994).

${ }^{17}$ Belotti, Petites Filles, "pour chacune” paperback edition, editor's note on back cover.

${ }^{18}$ See Sweatman, Risky Business, p.84.

${ }^{19}$ On this idea and theories of the feminine in French second-wave feminism, see chapter 5 in Duchen, Feminism in France, and chapter 4 in Greenwald, Daughters of 1968.

${ }^{20}$ The biographical information on Adela Turin and on the series is taken from Pavard, Des Femmes, pp. 88-91.

${ }^{21}$ Ibid., p. 88 .

${ }^{22}$ Interview with Adela Turin by Ghislaine Pesant, Revue Quebecoise de la Sociologie, c.1981, undated press clipping, Éditions des Femmes business archive. 
${ }^{23}$ Pavard, Des Femmes, p. 90.

${ }^{24}$ This was the reckoning of the Éditions des Femmes press office. The field of children's publishing and the second-wave feminist movement remains under-researched, so it is difficult to say definitively whether this was the case.

${ }^{25}$ See Sara Evans, Tidal Wave: How Women Changed America at Century's End (New York: Free Press, 2003, this edition 2004), pp. 12-13, 36. I would like to thank Kim Dhillon for her insights into the work of the Lollipop Power Collective.

${ }^{26}$ Evans, Tidal Wave, p. 12.

${ }^{27}$ Although it should be noted that there was a professionalism to the Éditions des Femmes project, as compared to the deliberately 'idealist' approach of the Torchon Brûle magazine, see Pavard, Des Femmes, p. 67.

${ }^{28}$ Adela Turin wrote and Nella Bosnia illustrated Après le Déluge; Clementine s'en va; L'Histoire Vraie des Bonobos à lunettes; Les Cinq Femmes de Barbargent; while Margherita Saccaro illustrated Turin's story Histoire de Sandwiches. Agnes Rosentiehl write and illustrated De la coiffure and Les Filles. Benoîte and Flora Groult wrote and illustrated Histoire de Fidèle. All titles published by Paris \& Milan: Éditions des Femmes, Du Côté des Petites Filles/ Dalla Parte delle Bambine, 1976. For bibliographical information on the series, 1976-1982, see the catalogue Mémoire de Femmes, 19742004, (Paris: Éditions des Femmes-Antoinette Fouque, 2004), 508-513.

${ }^{29}$ See Turin's comments to Pavard, Des Femmes, pp. 89-90.

${ }^{30}$ Pavard, Des Femmes, p. 89. In the absence of any records for the series from this period in the Éditions des Femmes business archives, it is difficult to verify Turin's claim. Catherine Guyot, the current head of press at Éditions des Femmes, confirmed these figures sounded plausible, given the number of international editions.

${ }^{31}$ On the Spanish venture, see Pavard, Des Femmes, p. 88. The English translations are held in the Women's Library at the London School of Economics.

${ }^{32}$ Adela Turin, Rosaconfetto/ Rose Bombonne, illustrated by Nella Bosnia (Paris \& Milan: Éditions des Femmes, Du Côté des Petites Filles/ Dalla Parte delle Bambine, 1975). Subsequent references to 
the series will just provide the year of publication. Where a title was published in French or Italian or English translation, I will provide the translations in brackets.

${ }^{33}$ Quoted in Sweatman, Risky Business, p. 79.

${ }^{34}$ Adela Turin, L'Histoire d'Ariane, illustrated by Noëlle Herrenschmidt (1980), conversation between the author and illustrator, appendix 2 .

${ }^{35}$ Edwige Talibon-Lapomme, 'Comment le féminisme vient aux filles', Le Monde 24 December 1976.

${ }^{36}$ Pavard, Des Femmes, p. 89.

${ }^{37}$ Paul, ‘Feminism Revisited', p. 119.

${ }^{38}$ Ibid., p.120.

${ }^{39}$ Editor's foreword to Hans Christian Andersen, illustrations by Nicole Claveloux, Poucette/ Mignolina (1978).

${ }^{40}$ Hans Christian Andersen, La Petite Sirène, illustrated by Nicole Claveloux (1980).

${ }^{41}$ Claveloux produced new illustrations for Hans Christian Andersen's La Petite Sirène (1980) and Poucette (1978), and George Sand, Brise et Rose (1977).

${ }^{42}$ Nicole Claveloux, email correspondence with the author, 16 August 2017.

${ }^{43}$ Bruel, 'Les Jardins Discrets de Nicole Claveloux', Revue des Livres pour Enfants 242 (September 2008), special number on Nicole Claveloux, p.113.

${ }^{44}$ See for example Isabelle Merlet's review for the magazine Jouet Conseil, February 1981, p.80, and the Éditions des Femmes business archives press clippings folder for the series.

${ }^{45}$ Nicole Claveloux, email correspondence with the author, 16 August 2017. 
${ }^{46}$ Tamara Chaplin, 'Orgasm Without Limits: May '68 and the History of Sex Education in Modern France', in May '68: Rethinking France's Last Revolution, ed. by Julian Jackson, Anna-Louise Milne, James Williams (London: Palgrave, 2011) 376 - 397.

47 ‘ 1965 , naissance d'une grande maison d'édition: L’École des loisirs. Entretien avec Jean Delas', Revue des livres pour enfants, 244 (2008), 125-33, p. 130.

${ }^{48}$ This was a re-edition of the book first published by Éditions des Jumeaux in 1969.

${ }^{49}$ Agnès Gay [Rosenstiehl] Des Filles (Paris: Éditions des Femmes, Du Côté des Petites Filles, 1976)

${ }^{50}$ Interview with Agnès Rosenstiehl by Véronique Châtel, Générations, March 2019, pp. 76-77 $<$ https://www.lavillebrule.com/Themes/v1/media/livre_presses_doc_512.pdf> [Accessed 31 May 2019].

${ }^{51}$ Ibid.

${ }^{52}$ Simone de Beauvoir's Deuxième Sexe explored the literature on urination and sex difference in children, vol 2, pp. 18-23.

${ }^{53}$ Interview with Agnès Rosenstiehl by Weronika Zarachowicz, Télérama, 16 January 2019, 3601, 31-33, <https://www.lavillebrule.com/Themes/v1/media/livre_presses_doc_493.pdf> [Accessed 31 May 2019].

${ }^{54}$ Rosenstiehl, interviewed by Marie Lallouet at the symposium 'Le 68 des enfants: albums en révolution, quel héritage?', 17 May 2018 at the Médiathèque Françoise Sagan, Paris.

${ }^{55}$ Quoted in Sweatman, Risky Business, p. 88.

${ }^{56}$ Bulletin du collectif 'Pour un autre merveilleux', July 1976. Fonds Sourire qui Mord, University of Clermont-Ferrand Special Collections, BCU cote C10124.

${ }^{57}$ Interview by the author with Christian Bruel, 7 October 2016.

${ }^{58}$ Lou Perdu, 'Les faiseuses d'images', Sorcières, 23 (1981) 122-8, p. 126. 
${ }^{59}$ Chiara, la bambina che aveva un'ombra-ragazzo, translated by Adela Turin, (Milan, Edizioni Dalla Parte delle Bambine, 1978); Clara, la chica que tenía sombra de chico translated by Humpty Dumpty (Barcelona, Lumen, 1980). See the translations listed in the Clermont-Ferrand Fonds Bruel inventory: <https://bmsh.hypotheses.org/files/2018/06/CatalogueFondsCBruel.pdf> [Accessed 2 October 2019].

${ }^{60}$ Interview by the author with Christian Bruel, 7 October 2016.

${ }^{61}$ Pavard, interview with Pavard, Des Femmes, pp. 90-91.

${ }^{62}$ Ibid., p. 89.

${ }^{63}$ Marie-Estelle Pech, 'Les livres pour enfants, des polémiques récurrentes', Le Figaro, 14 February 2014. 